\title{
The real UVB photoprotective efficacy of vegetable oils: in vitro and in vivo studies
}

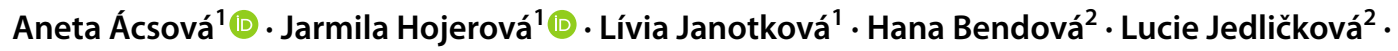

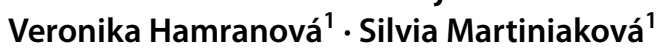

Received: 29 September 2020 / Accepted: 21 December 2020 / Published online: 19 January 2021

(c) The Author(s), under exclusive licence to European Photochemistry Association,European Society for Photobiology 2021

\begin{abstract}
Some vegetable oils are currently being promoted as a safe alternative to commercial sunscreens. The true UVB photoprotective efficacy of 14 virgin vegetable oils and the suitability of the dilution method for determining their SPF value were evaluated. Oils and standard sunscreens were investigated in vitro by the Mansur's method in Slovakia and in vivo by the ISO method in the Czech Republic. SPF values in vitro $(0.1 ; 0.0 ; 0.4 ; 0.2$ and 0.2$)$ and in vivo $(2.5 ; 1.2 ; 2.6 ; 2.6$; and 2.8$)$ of the five most promoted oils (from carrot seed, coconut, raspberry seed, rosehip seed, and wheat germ) were significantly lower than the values reported in the controversial studies. We have shown that the overestimated SPF values of these oils were determined by authors who did not strictly follow Mansur's original methodology. The other eight vegetable oils also provide no or negligible SPF values. Only the in vitro SPF value of 11.2 tamanu oil is worth mentioning, probably due to high proportion of calophyllolides. In vitro and in vivo SPF ratios from 1.14 to 0.94 obtained by two methods in two laboratories for six commercial sunscreen oils used as controls confirm the correctness of performing the Mansur's method in this study. However, this dilution method has proven to be fundamentally flawed in determining the SPF value of substances with such negligible photoprotection as most vegetable oils can provide. An SPF value of less than 1, which can be determined by this Mansur's method, is physiologically impossible and meaningless.
\end{abstract}

\section{Graphic abstract}

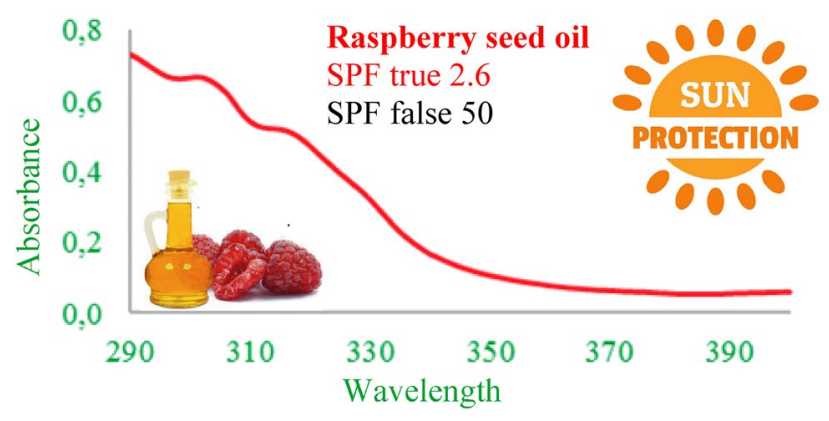

Keywords Vegetable oil $\cdot$ False SPF values $\cdot$ Sunscreen $\cdot$ Mansur's method

Jarmila Hojerová

jarmila.hojerova@stuba.sk

1 Faculty of Chemical and Food Technology, Laboratories of Cosmetology, Slovak University of Technology in Bratislava, Bratislava, Slovakia

2 The National Institute of Public Health in Prague, Centre of Toxicology and Health Safety, National Reference Centre for Cosmetics, Prague, Czech Republic

\section{Introduction}

In recent years, there has been a rapid increase in knowledge about the etiology, epidemiology, and prevention of both acute and chronic effects of excessive exposure to ultraviolet (UV) radiation (UVR) from the sun. A causal link between solar erythema, immunosuppression, pigment 
spots and accelerated skin aging, but also the development of skin cancer, i.e., malignant melanomas, basal and squamous cell carcinomas has been confirmed. Radiation in both UVB and UVA regions of the spectrum is genotoxic; UVB mainly causes direct DNA damage, while UVA causes oxidative DNA damage and many other harmful consequences $[1,2]$. Recommendation to use appropriate sunscreens to minimize skin damage caused by UVR and other factors, is therefore a key part of public health campaigns targeting mainly to the light-skinned population [1-3].

At present, however, the safety profiles of certain conventional sunscreen products are questioned due to their controversial toxicological effects, often referred as the "sunscreen's controversy". On one hand, they should protect the consumer's skin from harmful UVR, but on the other hand, some of their active ingredients may be potentially dangerous for the same consumer. This controversy mainly concerns some chemical UV filters used for decades. Unlike modern types of inorganic and hybrid UV filters, they protect the skin only by absorbing UVR. Some of their molecules are prone to degradation in the presence of sunlight/UVR. Irreversible photoreactions cause not only a reduction in photoprotection efficiency of this UV filter [3], but also the formation of photodegradation products which often lead to skin irritation or photodermatosis, including phototoxicity/ photoirritation and photoallergic reactions. Dermal absorption studies have shown that certain UV filters are able to penetrate through the skin in sufficient quantities to enter the systemic circulation [4-8] and interfere with endocrine system [9]. In addition, UV filters, either directly from the skin of consumers or from wastewaters, enter watercourses, seas, and oceans, where they have an adverse environmental impact $[9,10]$.

Therefore, a certain group of consumers is looking for natural alternatives to chemical UV filters. Recently, there has been a proliferation of websites devoted to promoting natural oils as safer topical alternatives to commercial sunscreens [11]. Oils from carrot seed, coconut, raspberry seed, rosehip seed, and wheat germ are five most widely promoted species, which should provide a favourable sun protection factor (SPF). In particular, the websites of some retailers of natural oils [12-15], etc., refer to the results of studies by Oomah et al. [16] or Kaur and Saraf [17] or Suryawanshi [18]. However, several other authors [19-22] argued that most vegetable oils provide no or negligible SPF values.

The first aim of this study was to investigate the real UVB photoprotective efficacy of the most promoted and other interesting virgin vegetable oils. The second objective was to verify the suitability of the dilution method according to Mansur et al. [23, 24] for this purpose, because this method was used to determine the SPF value of certain oils by the above-mentioned authors $[17,18]$.

\section{Material and methods}

\subsection{Chemicals and equipment}

The following chemicals were used: Eusolex ${ }^{\circledR}$ HMS, abbreviated HMS (INCI, Homosalate), UVB filter from Merck (Darmstadt, Germany); ingredients for the standard HMS sunscreen from cosmetics manufacturers in Slovakia; standard P2 sunscreen from Cosmonde, a.s. (Brno, Czech Republic); and UV-ethanol (min. 95\%) and petroleum ether $\left(40-60{ }^{\circ} \mathrm{C}\right)$, both of analytical grade, from Mikrochem Trade (Pezinok, Slovakia). The following equipment were used: (i) Shimadzu UV-1800 double beam UV/visible spectrophotometer (Shimadzu, Kyoto, Japan) equipped with two quartz cuvettes of $1 \mathrm{~cm}$ optical path and operated using Shimadzu UV-Probe PC software-for in vitro test; (ii) solar Simulator Model 601-300 Multiport ${ }^{\circledR}$ SPF Testing (Solar Light Co., Glenside, USA) and PMA 2100DCS (Dose Control System) Radiometer (Solar Light Co., Glenside, USA) — for in vivo test.

\subsection{Vegetable oils and sunscreen oils}

Fourteen vegetable single-species (non-volatile) oils were chosen. Above all, it was the five oils (carrot seed, coconut, raspberry seed, rosehip seed, and wheat germ) that are widely promoted for having a high SPF. The other nine oils were chosen as promising natural photoprotective agents, especially oils originating in the Indo-Pacific region, such as argan, black cumin, chaulmoogra, moringa, and tamanu seed. All these oils were branded products, labelled on the packaging as cold pressed, unrefined, organic, and some of them also as crude or naturally certified. The only exception was extra rosehip oil obtained by gentle supercritical extraction of seeds with carbon dioxide. The oils were obtained either directly from manufacturers or from suppliers, as listed in Table 1, and were protected from light until analysis.

As a control, six commercial sunscreen oils with SPF values from 6 to 30 (according to the label) from a Slovak manufacturer were also evaluated by the same in vitro test and in vivo test. The sunscreen oils were based on these substances (INCI names); sunscreen oil 1, 2, 4, and 6: Paraffinum Liquidum, C12-15 Alkyl Benzoate, Helianthus Annuus Seed Oil, Tocopheryl Acetate, Juglans Regia Seed Oil, Parfum, CI 12,010; sunscreen oil 3 and 5: Paraffinum Liquidum, Ethylhexyl Palmitate, C12-15 Alkyl Benzoate, Cyclopentasiloxane, Cyclohexasiloxane, Tocopheryl Acetate, Juglans Regia Seed Oil, Hippophae Rhamnoides Fruit Oil, Beta-Carotene, Parfum. The range of UV filters (\% $\mathrm{w} / \mathrm{w})$ in each sunscreen oil according to data provided by its manufacturer is given in Table 3 . 
Table 1 Fourteen virgin fixed vegetable oils evaluated by in vivo and in vitro tests for UVB photoprotection performance

\begin{tabular}{|c|c|c|c|c|c|}
\hline Vegetable oil name & INCI name & Method of isolation & Labelled & Product brand & Manufacturer or supplier \\
\hline Argan oil & $\begin{array}{l}\text { Argania Spinosa Kernel } \\
\text { Oil }\end{array}$ & $\begin{array}{l}\text { By expression of the } \\
\text { kernels, Argania spi- } \\
\text { nosa } L \text {. }\end{array}$ & Bio certified organic & Assouss Argane & Assouss Argane, Morocco \\
\hline Avocado oil & Persea Gratissima Oil & $\begin{array}{l}\text { By pressing the dehy- } \\
\text { drated sliced flesh } \\
\text { of the avocado pear, } \\
\text { Persea gratissima } L \text {. }\end{array}$ & Bio & Saloos & M+H Slovakia, Slovakia \\
\hline Black cumin oil & Nigella Sativa Seed Oil & $\begin{array}{l}\text { By cold pressing of the } \\
\text { seeds of Black Cara- } \\
\text { way, Nigella sativa L. }\end{array}$ & Bio raw & Inolex & Inolex Provence, France \\
\hline Carrot seed oil & $\begin{array}{l}\text { Daucus Carota Sativa } \\
\text { Seed Oil }\end{array}$ & $\begin{array}{l}\text { By cold pressing of the } \\
\text { seeds of the carrot, } \\
\text { Daucus carota L. }\end{array}$ & Bio raw & Dr. Feelgood & Dr. Feelgood, Germany \\
\hline Chaulmoogra oil & $\begin{array}{l}\text { Taraktogenos Kurzii Seed } \\
\text { Oil }\end{array}$ & $\begin{array}{l}\text { By cold pressing of the } \\
\text { seeds of Taraktogenos } \\
\text { kurzii }\end{array}$ & Bio raw & Inolex & Inolex Provence, France \\
\hline Coconut oil & Cocos Nucifera Oil & $\begin{array}{l}\text { By expression of the } \\
\text { kernels of the seeds } \\
\text { of the coconut, Cocos } \\
\text { nucifera } L \text {. }\end{array}$ & Bio certified natural & Purity Vision FT & $\begin{array}{l}\text { Purity Vision, Czech } \\
\text { Republic }\end{array}$ \\
\hline Hazelnut oil & $\begin{array}{l}\text { Gevuina Avellana Kernel } \\
\text { Oil }\end{array}$ & $\begin{array}{l}\text { By cold pressing of the } \\
\text { fruits of Gevuina avel- } \\
\text { lana } L .\end{array}$ & Bio raw & Dr. Feelgood & Dr. Feelgood, Germany \\
\hline Hemp oil & Cannabis Sativa Seed Oil & $\begin{array}{l}\text { By cold pressing of the } \\
\text { seeds of Cannabis } \\
\text { sativa } L \text {. }\end{array}$ & Bio certified natural & Saloos & M+H Slovakia, Slovakia \\
\hline Moringa seed oil & $\begin{array}{l}\text { Moringa Oleifera Seed } \\
\text { Oil }\end{array}$ & $\begin{array}{l}\text { By cold pressing of } \\
\text { the seeds of Moringa } \\
\text { oleifera } L \text {. }\end{array}$ & Certified natural & Renovality & $\begin{array}{l}\text { Pharmafit Czech, Czech } \\
\text { Republic }\end{array}$ \\
\hline Raspberry seed oil & Rubus Idaeus Seed Oil & $\begin{array}{l}\text { By cold pressing of the } \\
\text { seeds of the raspberry, } \\
\text { Rubus idaeus L. }\end{array}$ & Bio raw & Saloos & M+H Slovakia, Slovakia \\
\hline Rosehip seed oil & Rosa Canina Seed Oil & $\begin{array}{l}\text { By supercritical } \mathrm{CO}_{2} \\
\text { extraction of the seeds } \\
\text { of Rosa canina } L \text {. }\end{array}$ & Bio certified natural & Saloos & M+H Slovakia, Slovakia \\
\hline Shea butter & $\begin{array}{l}\text { Butyrospermum Parkii } \\
\text { Butter }\end{array}$ & $\begin{array}{l}\text { By cold pressing of the } \\
\text { fruits of the Shea Tree, } \\
\text { Butyrospernum parkii } \\
\text { L. }\end{array}$ & Bio raw & Dr. Feelgood & Dr. Feelgood, Germany \\
\hline Tamanu seed oil & $\begin{array}{l}\text { Calophyllum Inophyllum } \\
\text { Seed Oil }\end{array}$ & $\begin{array}{l}\text { By cold pressing of the } \\
\text { seeds of Calophyllum } \\
\text { inophyllum L. }\end{array}$ & Bio raw & Dr. Feelgood & Dr. Feelgood, Germany \\
\hline Wheat germ oil & $\begin{array}{l}\text { Triticum Vulgare Germ } \\
\text { Oil }\end{array}$ & $\begin{array}{l}\text { By cold pressing of the } \\
\text { wheat germ of Triticum } \\
\text { vulgare } L .\end{array}$ & Certified natural & Saloos & M+H Slovakia, Slovakia \\
\hline
\end{tabular}

\subsection{Standard sunscreen products}

Two standard sunscreens were selected as references. One is the standard $8 \%$ HMS sunscreen (SPF value of $4.47 \pm 1.279$ ) as suggested by Mansur et al. [23] in in vitro SPF test and by the US Food and Drug Administration (FDA) in in vivo SPF test [25]. It was prepared at the beginning of our in vitro study by the classical emulsification method from the phase A (HMS 8\% w/w, Lanolin 5\%, Petrolatum 2.5\%, Stearic
Acid 4\%, and Propylparaben 0.05\%) and phase B (Methylparaben $0.1 \%$, Disodium EDTA 0.05\%, Propylene Glycol $5 \%$, Triethanolamine $1 \%$, and Aqua $74.3 \%$ ) at $77-82{ }^{\circ} \mathrm{C}$. This standard HMS sunscreen was used as a reference in determining the in vitro SPF value of all the oils evaluated.

Another is the standard P2 sunscreen (SPF value of $16.1 \pm 2.42$ ) as suggested by the ISO 24,444 Method in in vivo SPF test [26] for a product at expected SPF value of $<20$ as well as $\geq 20$. It was prepared also by the classical emulsification method in Cosmonde, a. s. (Brno, Czech 
Republic) from the phase A (Ethylhexyl Dimethyl PABA 7.0\%, Lanolin 4.5\%, Benzophenone-3 3.0\% Glyceryl Stearate $3.0 \%$, Cocoa Butter 2.0\%, Stearic Acid 2.0\%), phase B (Aqua 71.6\%, Sorbitol 5.0\%, Triethanolamine 1.0\%, Methylparaben $0.3 \%$, Propylparaben $0.1 \%$ ) and phase C (Benzyl Alcohol $0.5 \%$ ) at $80-85{ }^{\circ} \mathrm{C}$ [26]. This standard P2 sunscreen was used as a reference in determining the in vivo SPF value of all the oils evaluated.

\subsection{Measurement of a sunscreen effectiveness}

The performance of a sunscreen is principally characterized by SPF and UVA-PF values. Given the stated aim of this study, we focused mainly on the value of SPF. In vivo, in vitro, and in silico methodologies are available for the determination of SPF. Regulatory bodies currently only approve the results of an in vivo method, while the other methods are useful in prediction.

\subsubsection{In vitro SPF measurement}

In vitro SPF measurement of the standard HMS sunscreen and all the oils tested was performed at the Cosmetic Laboratories of the Slovak University of Technology in Bratislava, Slovakia.

Several in vitro testing procedures have been suggested, but two major techniques are currently used. The first are methods whose principle is to measure the absorption or transmission of UVR through a film of sunscreen applied to a suitable substrate. Numerous studies have been performed over the years to verify the suitability of various substrates for this method, such as human stratum corneum ex vivo, various animal skin ex vivo, $3 \mathrm{M}$ Transpore tapes, biomembranes and quartz plates. Although there is no ideal substrate [27], adequately roughened and polymethyl methacrylate (PMMA) plates have been shown best mimic the relief of human skin [2, 3, 28, 29].

The second type are methods in which the absorption characteristics of the sunscreen agents are determined based on spectrophotometric analysis of dilute solutions. Because both "critical" studies" [17, 18] (see discussion) on the SPF of the most promoted oils were performed by a dilution test known as the Mansur's method, this one was also used in our study.

The method is based on two previous studies. Sayre et al. (1979) demonstrated the relationship between the erythemal efficiency spectrum and solar simulator intensity spectrum at each wavelength in the range of $290-320 \mathrm{~nm}$ as measured with a calibrated spectroradiometer (Table 2) and proposed the first equation for calculating in vitro SPF [30]. Lowe and Breeding [31] (1983) adjusted the calculation and introduced a correction factor based on a cream containing 8\% HMS. Finally, Mansur et al. [23] (1986) simplified
Table 2 The normalized relationship between the erythemal efficiency spectrum $(E E)$ and solar simulator intensity spectrum $(I)$ as measured with a calibrated spectroradiometer by Sayre et al. [30]

\begin{tabular}{ll}
\hline Wavelength $\lambda(\mathrm{nm})$ & $E E \times I$ (Normalized) \\
\hline 290 & 0.0150 \\
295 & 0.0817 \\
300 & 0.2874 \\
305 & 0.3278 \\
310 & 0.1864 \\
315 & 0.0839 \\
320 & 0.0180 \\
& $\Sigma E E \times I=1.0000$ \\
\hline
\end{tabular}

The values of $E E x I$ are constants

previous versions of the calculation to mathematical equation (Eq. 1) and described the procedure [24]. The principle of this method is to determine the SPF by spectrophotometric evaluation of a sample solution at a reference concentration of $0.20 \mathrm{mg} \mathrm{mL}^{-1}$ in a $1 \mathrm{~cm}$ quartz cuvette in the range 290-320 nm and increments of $5 \mathrm{~nm}$ [23]. The prescribed solvents in this method are ethanol for emulsions and ether for oils [23].

in vitro $S P F=C F \sum_{290}^{320} E E(\lambda) I(\lambda) A b s(\lambda)$

where, $C F$ is the correction factor $(=10), E E(\lambda)$ is the erythemal efficiency spectrum at a wavelength $\lambda, I(\lambda)$ is the solar simulator intensity spectrum a wavelength $\lambda$, and $A b s(\lambda)$ is the absorbance at a wavelength $\lambda$ of the sample diluted to a reference concentration of $0.20 \mathrm{mg} \mathrm{mL}^{-1}$.

2.4.1.1 Dilution of standard HMS sunscreen The FDA Code of Federal Regulations for the standard HMS sunscreen ${ }^{25}$ was followed. $1 \pm 0.0001 \mathrm{~g}$ of freshly prepared standard HMS sunscreen was weighed, transferred to a $100 \mathrm{~mL}$ volumetric flask, mixed with $50 \mathrm{~mL}$ of the extraction solvent ( $1 \%$ glacial acetic acid (v/v) in UV ethanol) using a vortex and heated in a water bath until clear. The solution cooled to room temperature was degassed in ultrasonic bath for $5 \mathrm{~min}$, diluted to a volume of $100 \mathrm{~mL}$ with degassed extraction solvent, and mixed well to make the $1 \%$ solution. This "stock solution" (SS) was filtered through Whatman filter paper 1, rejecting the ten first $\mathrm{mL}$. A $1.0 \mathrm{~mL}$ aliquot from $20 \mathrm{~mL}$ of the second filtrate obtained through filter paper 2 was added to a $50 \mathrm{~mL}$ volumetric flask, diluted to volume with extraction solvent and mixed well obtaining "the solution at the reference concentration" (SRC) of $0.20 \mathrm{mg} \mathrm{mL}^{-1}$, i.e., $0.02 \%(\mathrm{w} / \mathrm{v})(1: 50$ dilution of a $1 \% \mathrm{SS})$.

The absorption spectra of SRC for HMS sunscreen were obtained in the range of 290 to $400 \mathrm{~nm}$ with increments of 
Fig. 1 UVB absorption spectra of standard Homosalate sunscreen (HMS 8\%) and tamanu seed oil (raw bio) measured by the Mansur's method. Chemical formula of HMS is below the spectrum of this sunscreen. Chemical formula of calophyllolides (probably the main UVB photoprotective substances in tamanu seed oil) is above the spectrum of this oil. In vitro SPF values determined were 4.4 and 11.2 for standard HMS sunscreen and tamanu seed oil, respectively

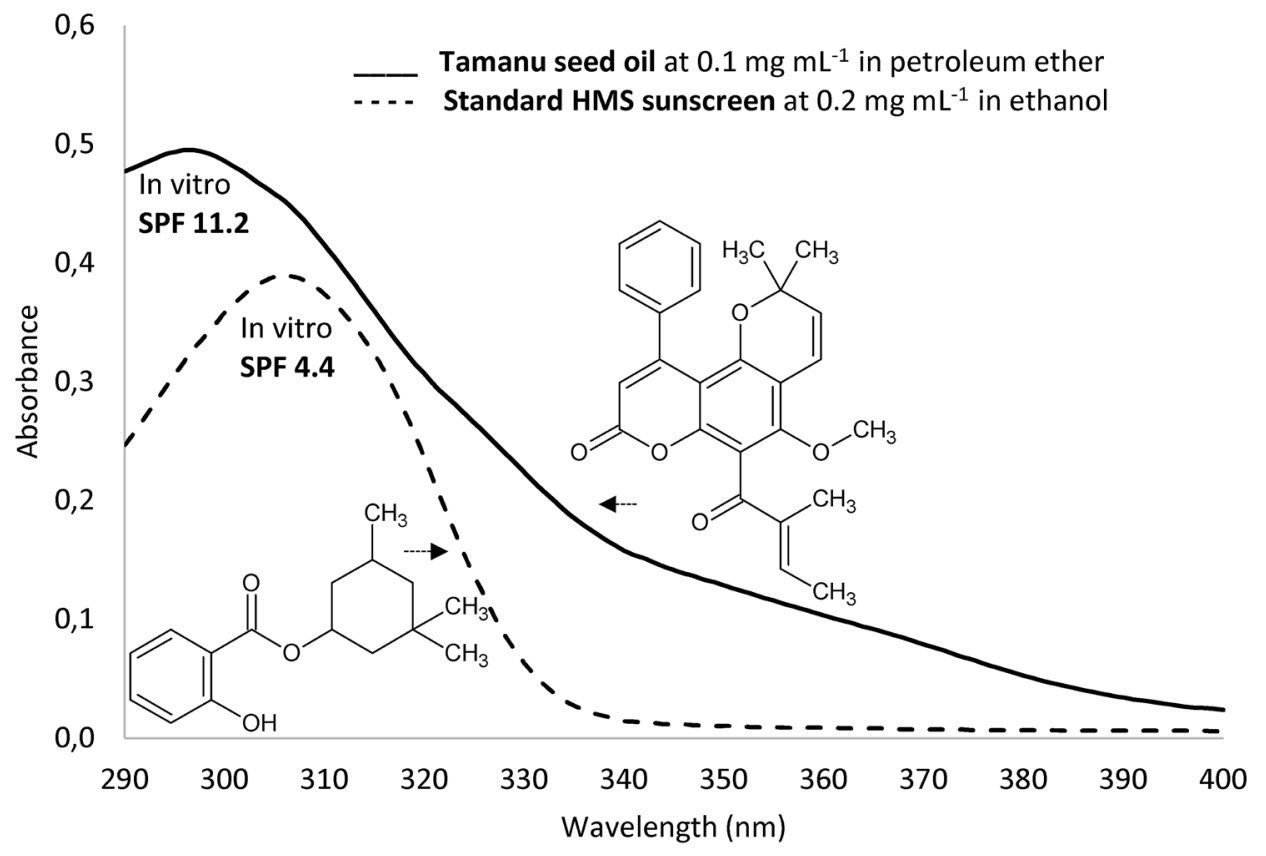

$1 \mathrm{~nm}$ (Shimadzu UV-1800 spectrophotometer and a quartz cuvette of $1 \mathrm{~cm}$ optical path) and ethanol as a blank (Fig. 1). The absorption data were obtained only in the range of 290 to $320 \mathrm{~nm}$, every $5 \mathrm{~nm}$, and three determinations were made at each point, followed by the application of Mansurequation (Eq. 1). The process of extraction and dilution of standard HMS sunscreen was repeated two more times. For illustration, the average absorbance values of SRC for standard HMS sunscreen are given in Tables 3 and 4.

\subsubsection{Dilution of sunscreen oils and vegetable oils $\mathrm{A}$} stock solution (1\%) of each oil was prepared as described above except heating. In accordance with the Mansur's methodology [23], petroleum ether was used as the extraction solvent instead of the ethanol prescribed for the emulsions. After discarding the first $10 \mathrm{~mL}$ of filtrate, approx. $3.5 \mathrm{~mL}$ of the filtrate from the second collection was added to a $1 \mathrm{~cm}$ quartz cuvette. The absorbance of this $1 \% \mathrm{SS}$ was determined spectrophotometrically as above, but petroleum ether was used as a blank. If the absorbance values were higher than 1.200 , the $1 \%$ SS was diluted again with petroleum ether. The absorbances for the "solution at the sample concentration" (SSC) were collected in triplicate for all the oils, except for tamanu oil, because due to surprising results, they were verified eight times. For illustration, the average absorbance values of the oils in SSC are given in Tables 3-5.

\subsubsection{In vivo SPF measurement}

The efficacy of commercial sunscreens for rating UVB (delayed sunburn) is primarily measured by the in vivo SPF.
An individual SPF (SPFi) value for a product is defined as the ratio of the Minimal Erythema Dose on product protected skin (MEDp) to the Minimal Erythema Dose on unprotected skin (MEDu) of the same subject. The MED in human skin is defined as the lowest ultraviolet UV dose that produces the first perceptible unambiguous erythema with defined borders appearing over most of the field of UV exposure, 16 to $24 \mathrm{~h}$ after UV exposure [26].

In this study, the in vivo SPF of the standard P2 sunscreen and all the oils was performed using the ISO 24,444 Method [26] at the accredited Laboratory of the National Institute of Public Health in Prague, Czech Republic. UV Simulator Model 601-300 (Solar Light Co., USA) fitted with a xenon $300 \mathrm{~W}$ short arc was used as the source of UVR. It delivered UVR with a continuous emission spectrum close to summer sunlight (95\% UVA, 5\% UVB) at homogeneity of $\geq 90 \%$ [32]. Relative cumulative erythema effectiveness (\% RCEE) of the UV solar simulator outputs meet the acceptance limits [32] according to ISO 24,444 Method [26]. The simulator irradiates an area of $5 \times 6 \mathrm{~cm}$ in 6 points (diameter $1 \mathrm{~cm}$ ) in a series of doses increasing geometrically (factor 1.25 and 1.12 for expected SPF value of $<25$ and $\geq 25$, respectively). Radiometer PMA 2100-Dose Control System was used for the measurement and automatic delivery of radiation doses.

Each sample was tested in a group of ten healthy human volunteers (age 33-69, gender female, Fitzpatrick's skin type I-III). The selection of volunteers as well as the entire study were performed in accordance with the principles described in the World Medical Association (WMA) Declaration of Helsinki for Medical Research Involving Human Subjects $[33,34]$. The study was approved by the Ethical Review Committee of the National Institute of 
Table 3 UVB photoprotection performance of the six sunscreen oils and the standard sunscreens determined in vitro and in vivo

\begin{tabular}{|c|c|c|c|c|c|c|c|c|}
\hline Sample & HMS sunscreen & Sunscreen oil 1 & Sunscreen oil 2 & Sunscreen oil 3 & Sunscreen oil 4 & Sunscreen oil 5 & Sunscreen oil 6 & P2 sunscreen \\
\hline \multicolumn{9}{|c|}{ UV filters content in two standard sunscreens and six commercial sunscreen oils } \\
\hline $\begin{array}{l}\text { Homosalate (\% } \\
\text { w/w) }\end{array}$ & 8 & & & & & & & \\
\hline Ethylhexyl Dimethy & $\operatorname{yl~PABA}(\% \mathrm{w} / \mathrm{w})$ & & & & & & & 7 \\
\hline Benzophenone-3 & $\% \mathrm{w} / \mathrm{w})$ & & & & & & & 3 \\
\hline $\begin{array}{l}\text { Octocrylene (\% } \\
\text { w/w) }\end{array}$ & & $1-5$ & $1-5$ & $5-10$ & $5-10$ & $5-10$ & $5-10$ & \\
\hline EHMC (\% w/w) & & $1-5$ & $1-5$ & $1-5$ & $5-10$ & $5-10$ & $5-10$ & \\
\hline $\operatorname{BMDM}(\% \mathrm{w} / \mathrm{w})$ & & $1-5$ & $1-5$ & $1-5$ & $1-5$ & $1-5$ & & \\
\hline BEMT (\% w/w) & & & & & & $1-5$ & $1-5$ & \\
\hline Labelled SPF & & 6 & 10 & 15 & 20 & 25 & 30 & \\
\hline \multicolumn{9}{|c|}{ In Vitro SPF determination } \\
\hline $\begin{array}{l}\text { Solution at the } \\
\text { reference } \\
\text { concentration } \\
\left(\mathrm{mg} \mathrm{mL}^{-1}\right)\end{array}$ & 0.2 & 0.2 & 0.2 & 0.2 & 0.2 & 0.2 & 0.2 & \\
\hline $\begin{array}{l}\text { Solution at } \\
\text { the sample } \\
\text { concentration } \\
\left(\mathrm{mg} \mathrm{mL}^{-1}\right)\end{array}$ & 0.2 & 0.2 & 0.2 & 0.1 & 0.1 & 0.1 & 0.05 & \\
\hline Dilution factor & 1.0 & 1.0 & 1.0 & 2.0 & 2.0 & 2.0 & 4.0 & \\
\hline $\begin{array}{l}\text { Absorbance at } \\
290 \mathrm{~nm}\end{array}$ & 0.2470 & 0.6330 & 0.9927 & 0.6427 & 0.8507 & 1.1250 & 0.7287 & \\
\hline $\begin{array}{l}\text { Absorbance at } \\
295 \mathrm{~nm}\end{array}$ & 0.3065 & 0.6137 & 0.9667 & 0.6420 & 0.8393 & 1.1267 & 0.7313 & \\
\hline $\begin{array}{l}\text { Absorbance at } \\
300 \mathrm{~nm}\end{array}$ & 0.3585 & 0.5963 & 0.9417 & 0.6353 & 0.8223 & 1.1210 & 0.7287 & \\
\hline $\begin{array}{l}\text { Absorbance at } \\
305 \mathrm{~nm}\end{array}$ & 0.3885 & 0.5860 & 0.9267 & 0.6263 & 0.8120 & 1.1217 & 0.7273 & \\
\hline $\begin{array}{l}\text { Absorbance at } \\
310 \mathrm{~nm}\end{array}$ & 0.3740 & 0.5441 & 0.8610 & 0.5850 & 0.7617 & 1.0687 & 0.6810 & \\
\hline $\begin{array}{l}\text { Absorbance at } \\
315 \mathrm{~nm}\end{array}$ & 0.3235 & 0.4862 & 0.7700 & 0.5297 & 0.6910 & 0.9907 & 0.6160 & \\
\hline $\begin{array}{l}\text { Absorbance at } \\
320 \mathrm{~nm}\end{array}$ & 0.2360 & 0.3941 & 0.6260 & 0.4463 & 0.5800 & 0.8760 & 0.5173 & \\
\hline $\begin{array}{l}\text { Found SPF } \\
\text { in vitro } \pm \mathrm{SD} \text {, } \\
\qquad \mathrm{CF}=10, n=3\end{array}$ & $\mathbf{3 . 6 0} \pm 0.47$ & & & & & & & \\
\hline $\begin{array}{l}\text { Found SPF } \\
\text { in vitro modi- } \\
\text { fied } \pm \mathrm{SD}, \\
\mathrm{CFa}=12.4 \\
n=3 \mathrm{SD} \\
\mathrm{CFa}=12.4 \\
n=3\end{array}$ & 4.43 & $\mathbf{7 . 0} \pm 0.1$ & $\mathbf{1 1 . 1} \pm 0.1$ & $\mathbf{1 5 . 2} \pm 1.8$ & $19.7 \pm 0.8$ & $\mathbf{2 7 . 2} \pm 0.4$ & $35.0 \pm 3.0$ & \\
\hline \multicolumn{9}{|c|}{ In vivo $S P F$ determination } \\
\hline $\begin{array}{l}\text { Found SPF } \\
\quad \text { in vivo } \pm \text { SD } \\
n=10\end{array}$ & & $6.2 \pm 1.4$ & $\mathbf{9 . 8} \pm 1.3$ & $\mathbf{1 5 . 0} \pm 1.9$ & $\mathbf{2 0 . 9} \pm 1.8$ & $25.8 \pm 3.1$ & $\mathbf{3 0 . 7} \pm 3.1$ & $15.8 \pm 2.0$ \\
\hline SPF $95 \%$ CI & & $5.3-7.1$ & $9.0-10.6$ & $13.8-16.2$ & $19.8-22.1$ & $23.9-27.7$ & $28.7-32.7$ & $14.4-17.3$ \\
\hline
\end{tabular}

EHMC Ethylhexyl Methoxycinnamate, BMDM Butyl Methoxydibenzoylmethane, BEMT Bis-Ethylhexyloxyphenol Methoxyphenyl Triazine, $P A B A$ p-Aminobenzoic Acid

The final values in vitro and in vivo SPF are indicated in bold. The SPF values are stated for concentrated oils. The absorbance values (the arithmetic mean of " $n$ " measurements) are shown here for illustration purposes only

Public Health in Prague, Czech Republic. For each volunteer six skin areas $(5 \times 6 \mathrm{~cm})$ were delineated on the back, within the region between the scapula line and the waist. Prior to the test, the determination of individual MEDu for all volunteers was performed. The first delineated area (unprotected skin) was irradiated with a basic series of six UVR doses (11-33 $\mathrm{mJ} \mathrm{cm}^{-2}$ and $15-26 \mathrm{~mJ} \mathrm{~cm}^{-2}$ for oil with expected $\mathrm{SPF}<25$ and $\mathrm{SPF} \geq 25$, respectively). The standard P2 sunscreen and test oils were deposited on the delineated areas with a syringe in the amount of 
Table 4 UVB photoprotection performance of the seven virgin vegetable oils and the standard HMS sunscreen determined in vitro and in vivo

\begin{tabular}{|c|c|c|c|c|c|c|c|c|}
\hline Sample & $\begin{array}{l}\text { Standard } \\
\text { HMS sun- } \\
\text { screen }\end{array}$ & Argan oil & Avocado oil & $\begin{array}{l}\text { Black cumin } \\
\text { seed oil }\end{array}$ & $\begin{array}{l}\text { Carrot seed } \\
\text { oil* }\end{array}$ & $\begin{array}{l}\text { Chaulmo ogra } \\
\text { oil }\end{array}$ & Coconut oil & Hazelnut oil \\
\hline \multicolumn{9}{|c|}{ In vitro SPF determination } \\
\hline $\begin{array}{l}\text { Solution at the } \\
\text { reference } \\
\text { concentration } \\
\left(\mathrm{mg} \mathrm{mL}^{-1}\right)\end{array}$ & 0.2 & 0.2 & 0.2 & 0.2 & 0.2 & 0.2 & 0.2 & 0.2 \\
\hline $\begin{array}{l}\text { Solution at } \\
\text { the sample } \\
\text { concentration } \\
\left(\mathrm{mg} \mathrm{mL}^{-1}\right)\end{array}$ & 0.2 & 10.0 & 10.0 & 10.0 & 10.0 & 10.0 & 10.0 & 10.0 \\
\hline Dilution factor & 1.0 & 0.02 & 0.02 & 0.02 & 0.02 & 0.02 & 0.02 & 0.02 \\
\hline $\begin{array}{l}\text { Absorbance at } \\
290 \mathrm{~nm}\end{array}$ & 0.2470 & 0.6320 & 0.4693 & 0.5123 & 0.6390 & 0.2910 & 0.0381 & 0.3070 \\
\hline $\begin{array}{l}\text { Absorbance at } \\
295 \mathrm{~nm}\end{array}$ & 0.3065 & 0.4720 & 0.3947 & 0.4373 & 0.4757 & 0.1620 & 0.0312 & 0.1483 \\
\hline $\begin{array}{l}\text { Absorbance at } \\
300 \mathrm{~nm}\end{array}$ & 0.3585 & 0.4707 & 0.3477 & 0.3650 & 0.4083 & 0.1153 & 0.0246 & 0.0970 \\
\hline $\begin{array}{l}\text { Absorbance at } \\
305 \mathrm{~nm}\end{array}$ & 0.3885 & 0.3930 & 0.3147 & 0.2770 & 0.3237 & 0.0833 & 0.0190 & 0.0533 \\
\hline $\begin{array}{l}\text { Absorbance at } \\
310 \mathrm{~nm}\end{array}$ & 0.3740 & 0.2740 & 0.2913 & 0.1900 & 0.2727 & 0.0577 & 0.0162 & 0.0223 \\
\hline $\begin{array}{l}\text { Absorbance at } \\
315 \mathrm{~nm}\end{array}$ & 0.3235 & 0.2943 & 0.2787 & 0.1520 & 0.2783 & 0.0507 & 0.0144 & 0.0163 \\
\hline $\begin{array}{l}\text { Absorbance at } \\
320 \mathrm{~nm}\end{array}$ & 0.2360 & 0.2287 & 0.2570 & 0.1303 & 0.2853 & 0.0393 & 0.0133 & 0.0083 \\
\hline $\begin{array}{l}\text { Found SPF } \\
\text { in vitro } \pm \mathrm{SD}, \\
\mathrm{CF}=10, n=3\end{array}$ & $\mathbf{3 . 6 0} \pm 0.47$ & & & & & & & \\
\hline $\begin{array}{l}\text { Found SPF } \\
\text { in vitro modi- } \\
\text { fied } \pm \mathrm{SD}, \\
\mathrm{CFa}=12.4 \\
n=3\end{array}$ & 4.43 & $\mathbf{0 . 0 9 7} \pm 0.001$ & $\mathbf{0 . 0 8 1} \pm 0.002$ & $\mathbf{0 . 0 7 2} \pm 0.001$ & $\mathbf{0 . 0 8 7} \pm 0.002$ & $\mathbf{0 . 0 2 3} \pm 0.002$ & $\mathbf{0 . 0 0 4} \pm 0.001$ & $\mathbf{0 . 0 1 7} \pm 0.003$ \\
\hline \multicolumn{9}{|c|}{ In vivo SPF determination } \\
\hline $\begin{array}{l}\text { Found SPF } \\
\text { in vivo } \pm \text { SD, } \\
n=10, \quad \text { SPF } \\
95 \% \text { CI }\end{array}$ & & $3.2 \pm 0.7$ & $2.7 \pm 0.4$ & $2.7 \pm 0.6$ & $2.5 \pm 0.6$ & $3.0 \pm 0.4$ & $1.2 \pm 0.1$ & $\mathbf{2 . 5} \pm 0.6$ \\
\hline SPF $95 \%$ CI & & $2.7-3.7$ & $2.4-3.0$ & $2.3-3.3$ & $2.1-2.9$ & $2.7-3.3$ & $1.1-1.3$ & $2.1-2.9$ \\
\hline
\end{tabular}

The final values in vitro and in vivo SPF are indicated in bold. The SPF values are stated for concentrated oils. The absorbance values (the arithmetic mean of " $n$ " measurements) are shown here for illustration purposes only. *Not to be confused with essential oil obtained by distillation from carrot seed

$2 \pm 0,05 \mathrm{mg} \mathrm{cm}^{-2}$ and spread over the whole test site vertically and horizontally with a finger (spreading time approx. $30 \mathrm{~s}$ ). The application was performed $15 \mathrm{~min}$ before irradiation. To confirm the SPF value (16.1) of the standard P2 sunscreen [26], the second area was exposed to a series of six doses of UVR $\left(\mathrm{mJ} \mathrm{cm}^{-2}\right)$ equal to, 1.25 times higher and 1.25 lower than 16 times the value of MEDui. To determine the MEDpi for 4 of the 14 vegetable oils the third to sixth areas were exposed to a series of 6 doses of UVR $\left(\mathrm{mJ} \mathrm{cm}^{-2}\right)$ equal to, 1.25 times higher and
1.25 lower than 4 times the value of MEDui. The same procedure was followed for the sunscreen oils, except that the skin areas were irradiated by a series of UV doses corresponding with the expected SPF of the products, i.e., the UV dose used in the determination of MEDu was multiplied by the SPF value on the packaging (factor 1.25 and 1.12 for $\mathrm{SPF}$ value of $<25$ and $\geq 25$, respectively). Visual assessment of skin reactions in all the areas was performed at $20 \pm 4 \mathrm{~h}$ post irradiation by the judgement of a trained evaluator in accordance with the ISO 24,444 Method [26]. 
Table 5 UVB photoprotection performance of the seven virgin vegetable oils and the standard P2 sunscreen determined in vitro and in vivo

\begin{tabular}{|c|c|c|c|c|c|c|c|c|}
\hline Sample & Hemp oil & $\begin{array}{l}\text { Moringa seed } \\
\text { oil }\end{array}$ & $\begin{array}{l}\text { Raspberry } \\
\text { seed oil }\end{array}$ & $\begin{array}{l}\text { Rosehip seed } \\
\text { oil }\end{array}$ & Shea butter & Tamanu seed oil & $\begin{array}{l}\text { Wheat germ } \\
\text { oil }\end{array}$ & $\begin{array}{l}\text { Standard } \\
\text { P2 sun- } \\
\text { screen }\end{array}$ \\
\hline \multicolumn{9}{|c|}{ In vitro SPF determination } \\
\hline $\begin{array}{l}\text { Solution at the } \\
\text { reference } \\
\text { concentration } \\
\left(\mathrm{mg} \mathrm{mL}^{-1}\right)\end{array}$ & 0.2 & 0.2 & 0.2 & 0.2 & 0.2 & 0.2 & 0.2 & \\
\hline $\begin{array}{l}\text { Solution at } \\
\text { the sample } \\
\text { concentration } \\
\left(\mathrm{mg} \mathrm{mL}^{-1}\right)\end{array}$ & 10.0 & 10.0 & 4.0 & 4.0 & 1.0 & 0.1 & 5.0 & \\
\hline Dilution factor & 0.02 & 0.02 & 0.05 & 0.5 & 0.20 & 2.00 & 0.04 & \\
\hline $\begin{array}{l}\text { Absorbance at } \\
290 \mathrm{~nm}\end{array}$ & 0.3153 & 0.6320 & 0.7293 & 0.4760 & 0.8740 & 0.4773 & 0.6297 & \\
\hline $\begin{array}{l}\text { Absorbance at } \\
295 \mathrm{~nm}\end{array}$ & 0.2650 & 0.4340 & 0.6767 & 0.3810 & 0.5507 & 0.4937 & 0.4857 & \\
\hline $\begin{array}{l}\text { Absorbance at } \\
300 \mathrm{~nm}\end{array}$ & 0.2423 & 0.3487 & 0.6650 & 0.3983 & 0.4083 & 0.4860 & 0.4457 & \\
\hline $\begin{array}{l}\text { Absorbance at } \\
305 \mathrm{~nm}\end{array}$ & 0.2253 & 0.2773 & 0.6367 & 0.3540 & 0.1210 & 0.4583 & 0.3840 & \\
\hline $\begin{array}{l}\text { Absorbance at } \\
310 \mathrm{~nm}\end{array}$ & 0.1410 & 0.1887 & 0.5397 & 0.2600 & 0.0707 & 0.4150 & 0.3443 & \\
\hline $\begin{array}{l}\text { Absorbance at } \\
315 \mathrm{~nm}\end{array}$ & 0.1270 & 0.1607 & 0.5187 & 0.2937 & 0.0550 & 0.3597 & 0.3500 & \\
\hline $\begin{array}{l}\text { Absorbance at } \\
320 \mathrm{~nm}\end{array}$ & 0.1287 & 0.1393 & 0.4703 & 0.2390 & 0.0473 & 0.3067 & 0.2863 & \\
\hline $\begin{array}{l}\text { Found SPF } \\
\text { in vitro modi- } \\
\text { fied } \pm \text { SD, } \\
\begin{array}{l}C F a=12.4 \\
n=3, *_{n}=8\end{array}\end{array}$ & $\mathbf{0 . 0 5 2} \pm 0.003$ & $\mathbf{0 . 0 7 1} \pm 0.002$ & $\mathbf{0 . 3 8 4} \pm 0.016$ & $\mathbf{0 . 2 1 5} \pm 0.014$ & $\mathbf{0 . 5 8 0} \pm 0.036$ & $11.170 * \pm 0.429$ & $\mathbf{0 . 1 9 9} \pm 0.002$ & \\
\hline \multicolumn{9}{|c|}{ In vivo SPF determination } \\
\hline $\begin{array}{l}\text { Found SPF } \\
\text { in vivo } \pm S D \\
n=10\end{array}$ & $2.5 \pm 0.6$ & $2.9 \pm 0.6$ & $2.6 \pm 0.5$ & $2.6 \pm 0.6$ & $4.5 \pm 1.0$ & $4.1 \pm 1.0$ & $2.8 \pm 0.6$ & $15.8 \pm 2.0$ \\
\hline SPF 95\% CI & $2.1-2.9$ & $2.5-3.5$ & $2.3-3.0$ & $2.2-3.0$ & $3.8-5.2$ & $3.4-4.8$ & $2.4-3.2$ & $14.4-17.3$ \\
\hline
\end{tabular}

The final SPF values in vitro and in vivo are indicated in bold. The SPF values are stated for concentrated oils. The absorbance values (the arithmetic mean of " $n$ " measurements) are shown here for illustration purposes only

\subsection{Statistical analyses}

The arithmetic mean of in vitro SPF value and the standard deviation (SD) was calculated using the software program Microsoft Office Excel 2016 for Windows. The statistical criteria described in ISO 24,444 Method [26] were used to evaluate the in vivo results, and a $95 \%$ confidence interval (CI) based on the mean and SD were calculated using the Eq. 2abc.

$95 \% \mathrm{CI}=S P F-c \leftrightarrow S P F+c$

$\mathrm{c}=t \frac{S D}{\sqrt{ } n}$
$C I[\%]=\frac{100 * c}{S P F} \leq 17 \%$

where, $n$ is $10, S D$ is standard deviation of the mean SPF, $t$ is $t$ value from the two-sided Student's t table at a probability level $p=0,05$ and with degrees of freedom $n=(n-1)$.

\section{Results and discussion}

\subsection{In vitro SPF of the standard HMS sunscreen}

The absorbance data were used individually in the Mansur-Eq. (1), and three in vitro SPF values were calculated. 
Their arithmetic mean and the standard deviation is given in Tables 3 and 4. For the SPF determination of a test product to be considered valid, the SPF of the standard HMS sunscreen in the parallel test must fall within the standard deviation of the expected SPF $(4.47 \pm 1.279)$ and the $95 \%$ confidence interval for the mean SPF must be 4 [25]. Since an average in vitro SPF value of $3.60 \pm 0.47$ was obtained for the standard HMS sunscreen in our study, the requirements for the acceptability of results were met. Then the actual correction factor $(\mathrm{CFa})$ of 12.4 was calculated by the Eq. (3) and used in all subsequent in vitro SPF calculations in our study.

$C F a=10 \frac{\text { in vivo } S P F H M S}{\text { in vitro } S P F H M S}=10 \frac{4.47}{3.60}=12.4$

where, $C F a$ is the correction factor actual for this study, 10 is the correction factor using the Mansur-equation, in vivo $S P F H M S$ is the value of the standard HMS sunscreen by the FDA [25], in vitro $S P F H M S$ is the value of the standard HMS sunscreen by the result of this study.

\subsection{In vitro SPF of sunscreen oils and vegetable oils - calculation}

The individual absorbance data for each oil were added in the Eq. (4) and the SPF individual (SPFi) in vitro was calculated

in vitro $S P F i=C F a \sum_{290}^{320} E E(\lambda) I(\lambda) A b s(\lambda) D F$

where, $C F a$ is the $\mathrm{CF}$ actual for this study $(=12.4) ; E E(\lambda)$, $I(\lambda)$, and $A b s(\lambda)$ are the same data as in Eq. (1), and $D F$ is the dilution factor determined for each sample in this study as a ratio of the reference concentration $\left(0.2 \mathrm{mg} \mathrm{mL}^{-1}\right)$ according to Mansur's method [23] to the final sample concentration $\left(\mathrm{mg} \mathrm{mL}^{-1}\right)$.

The arithmetic mean and SD of three in vitro SPFi values of the 6 commercial sunscreen oils are given in Table 3 and of 7 from 14 vegetable oils in Tables 4 and 5.

\subsection{In vivo SPF of sunscreen oils and vegetable oils - calculation}

The individual SPF (SPFi) of each product on each subject tested was calculated as the ratio of MEDpi to MEDui [26] according to the Eq. (5).

in vivo $S P F i=\frac{M E D p i}{M E D u i}$

where, in vivo $S P F i$ is an individual $\mathrm{SPF}, M E D p i\left(\mathrm{~mJ} \mathrm{~cm}^{-2}\right)$ is the MED of individual on protected skin with an oil, and
MEDui $\left(\mathrm{mJ} \mathrm{cm}^{-2}\right)$ is the MED of individual on unprotected skin.

Finally, in vivo SPF for each sample was calculated as the arithmetic mean of the ten in vivo SPFi values obtained from all ten subjects tested. The resulting in vivo SPF values of the 6 commercial sunscreen oils and the standard P2 sunscreen are shown in Table 3 and of 7 from 14 vegetable oils are given in Tables 4 and 5. In Tables 3-5, the CI value is indicated by two limits: CI-lower and CI-upper. Because the $95 \%$ CI for the mean SPF falls within the range $\pm 17 \%$, all 10 results for standard P2 sunscreen, 6 sunscreen oils and 14 vegetable oils on all subjects tested can be considered valid. The statistical criteria according to EN ISO 24,444 [26] have been met.

\subsection{In vitro SPF and in vivo SPF of commercial sunscreen oils}

When comparing the in vitro and the in vivo SPF values of six commercial sunscreen oils (Table 3 ), the ratios $1.13,1.13,1.01,0.94,1.05$, and 1.14 for oil no. 1, 2, 3, 4,5 , and 6, respectively, are found. These good correlations of results for commercial sunscreen oils obtained by two different methods in two country laboratories for six commercial sunscreens used as controls confirm the credibility of performing the Mansur's method in this study. A good agreement between the SPF values for products with $\mathrm{SPF} \geq 6$ determined by Mansur's in vitro methodology and the in vivo methodology has also been found in other studies [30, 35-39]. Unlike the special spectrophotometer required for the in vitro PMMA plate method, only a standard laboratory spectrophotometer is sufficient for this in vitro dilution method. We think, if performed correctly, this fast, inexpensive, and easy-to-use Mansur's method can be useful in estimating and screening SPF during sunscreen development for products with $S P F \geq 6$.

\subsection{UVB photoprotection performance of vegetable oils}

The SPF values of the five most promoted oils (Tables 4 and 5) were significantly lower ( 0.1 and 2.5 for carrot seed oil, 0.0 and 1.2 for coconut oil, 0.4 and 2.6 for raspberry seed oil, 0.2 and 2.6 for rosehip seed oil and 0.2 and 2.8 for wheat germ oil, in the in vitro test and the in vivo test, respectively), as SPF 4-50 declared by some researchers [16-18]. The SPF values of the other eight oils ranged from 0.02 (hazelnut and chaulmoogra seed) to 0.58 (shea butter) when determined in vitro and 2.5 (chaulmoogra, hemp and black cumin oils) to 4.5 (shea butter) in in vivo determinations (Tables 4 and 5).

The result that 13 of the 14 evaluated vegetable oils showed the SPF value of less than 1 in our in vitro test 
is meaningless and physiologically impossible. The SPF value provided by a substance/product must be at least 1 (see Eq. 5). Since Mansur's equation makes it possible to determine the SPF value even equal to zero (see Eq. 1), it is clear that this method is inappropriate and fundamentally incorrect in determining the SPF value of a substance/product with as low UVB protection as most vegetable oils is able to provide.

Our findings about the very weak effectiveness against UVB radiation of 13 of the 14 virgin vegetable oils determined also by in vivo method (from 1.2 to 4.5 ) are quite expected. These oils consist of triglycerides of common saturated, monounsaturated and polyunsaturated fatty acids without the presence of conjugated bonds and apparently do not contain enough accompanying substances with UVB chromophores in the molecules that would be able to significantly absorb UVB radiation.

Other researchers reached similar results. Ranjithkumaret et al. [18] in 2016 examined some vegetable oils also by the method of Mansur and confirmed that typical vegetable oils are not able to absorb enough UVB radiation. The authors found that, e.g., avocado oil performed the SPF value of only 0.03 at a concentration of $0.05 \%$, which is even less than in our study (SPF 0.08 at $0.02 \%$ ). Souza et al. [19] used the method of Mansur to study the opuntia seed oil as a promising UVB protector and showed that the oil provided no SPF at a reference concentration of $0.2 \mathrm{mg} \mathrm{mL}^{-1}$ [19]. Wagemaker et al. [40] performed a comprehensive study on the lipid fraction of ten roasted Coffea species obtained by extraction with petroleum ether. When the coffee oils were subjected to Mansur's methodology, no or low SPF (value from zero to 4.1) was determined. Kumar and Viswanathan [20] examined UV transmission through several vegetable and animal oils. Although the authors did not determine the SPF, they reported that coconut, peanut, cod liver, and mustard oil show very poor, neem and castor oil weak efficacy against UVB radiation. Only in chicken oil, due to the presence of a large number of molecules of conjugated unsaturated alkenes, a more remarkable absorption of UVB radiation was observed [20]. Gause and Chauhan [21] measured the molar UV-absorptivity of canola, citronella, coconut, olive, and soybean oil dissolved in ethanol and found that none of them could block UVR and their SPF would be very close to 1 .

Although these vegetable oils showed negligible absorption in the UVB region, some of them slightly increased the protection against reddening of the skin (Table 4-5, in vivo SPF value $\geq 2$ ). We hypothesize that this effect may be due to accompanying substances in the oil, such as tocopherols, phytosterols, carotenoids (zeaxanthin, beta-carotene, lutein, cryptoxanthin, etc.), which have anti-inflammatory, anti-erythema, antioxidant, and other biological activities. These compounds can also quench reactive oxygen species in the skin induced by UV radiation and avoid their detrimental reaction with skin proteins and membrane lipids. In addition, they could be able to prevent the formation of damaged DNA products, e.g., cyclobutane-pyrimidine dimers and thymine-cytosine (6-4) dimers [41].

\subsection{Cause of false SPF data on vegetable oils}

The question, therefore, remains what caused the hype in the photoprotection capabilities of vegetable oils. The first source for these claims seems to be a paper from Oomah et al. [16] of 2000. The authors state in this article that "the optical transmission of raspberry seed oil, especially in the UV range (290-400 nm) was comparable to that of titanium dioxide preparations with sun protection factor for UV-B (SPF) and protection factor for UV-A (PFA) values between $28-50$ and $6.75 \pm 7.5$, respectively". However, the paper does not provide any reference to a scientific study to underpin this claim, except for the reference to the commercial company (Kobo Products Inc., NJ) [16]. The huge range of SPF from 28 to 50 indicates that no standard SPF tests have been performed for this oil.

Kaur and Saraf [17] determined spectrophotometrically by the method of Mansur the SPF of the same non-volatile and volatile oils in aqueous ethanolic solutions. They stated that the SPF value of olive oil and coconut oil was found to be around 8, castor oil around 6, almond oil around 5, mustard oil, and chaulmoogra oil around 3, and sesame oil around 2. However, there were three major discrepancies with Mansur's methodology in this study. First, instead of ether recommended by Mansur et al. [23]. For oils, an aqueous-alcoholic solution was used. Due to the presence of water, the clarity of the solution could not be achieved. Second, the sample concentration at $0.1 \%$ used was higher than that (of $0.02 \%$, i.e., $0.2 \mathrm{mg} \mathrm{mL}^{-1}$ ) required by Mansur et al. [23], so about a five-fold increase in SPF value was determined. Finally, no comparison with the standard HMS sunscreen was described in the study by Kaur and Saraf [17].

A similar mistake was made in a recent study by Alfeetouri et al. [42] (2019). A dilute vegetable oil solution with a concentration of $10^{3} \mathrm{ppm}$ (i.e., $0.1 \%$ ) was evaluated spectrophotometrically, however, no dilution factor was used to calculate SPF according to Mansur's equation. Therefore, in vitro SPF values, e.g., 2.0 for carrot oil, 2.8 for rosehip oil, and 6.5 for wheat germ oil, found by the authors, could be about five times higher than the real in vitro SPF values. In addition, ethanol and cyclohexane were used as solvents instead of ether, and the reproducibility of SPF results was not verified on the standard HMS sunscreen.

In another study using Mansur's mathematical equation, Suryawanshi [18] in 2016 found in vitro SPF values of jojoba, olive, carrot, and wheat germ oils of $6,9,19$, and 22 , respectively. But the concentration of the oils was not 
specified in this work. Due to unacceptably high absorbance values, especially for wheat germ and carrot oils (3.5 to 3.0), it can be assumed that the recommended dilution of oil was not followed. Subsequently, the oils are being recommended for homemade sunscreens as a safe natural alternative to commercial sunscreens [43-45], etc. The recipes, which in addition to natural oils sometimes contain zinc oxide (of unknown particle size, efficacy, and safety), are risky because they are not regulated or tested for efficacy such as commercial sunscreens [11, 43-45].

\subsection{In vitro SPF of tamanu seed oil}

Tamanu seed oil was the only sample of the fourteen vegetable oils tested that showed an interesting absorption profile in the UVB range. As can be seen from Fig. 1, the absorption performance of this oil $(\lambda \max =296 \mathrm{~nm})$ at a concentration of $0.1 \mathrm{mg} \mathrm{mL}^{-1}$ (i.e. $0.01 \% \mathrm{w} / \mathrm{v}$ ) in petroleum ether was comparable to that of the standard HMS sunscreen $(\lambda \max =306 \mathrm{~nm})$ at $0.2 \mathrm{mg} \mathrm{mL}^{-1}$ (i.e., $0.02 \%$ $\mathrm{w} / \mathrm{v}$ ) in ethanol containing $0.0016 \%(\mathrm{w} / \mathrm{v})$ pure HMS. The determined in vitro SPF value of this oil was unexpectedly high - approx. 11.2, while the in vivo $S P F$ value $(4.1 \pm 1)$ appeared to be at the level of shea butter $(4.5 \pm 1)$. Although the disproportion between in vitro and in vivo SPF values was surprising, we found studies confirming both of our results. In the only published study we were able to find regarding the in vivo SPF value of tamanu oil, the SPF value is reported to be around $4.7(4.3-5.0, n=10)$ [46], which is consistent with our result in vivo $(4.1 \pm 1, n=10)$. Rejeki and Wahyuningsih [47] in a study using the dilution method determined the in vitro SPF value of tamanu oil as $10.34 \pm 0.06$ at a concentration of $0.2 \mathrm{mg} \mathrm{mL}^{-1}$, corresponding almost to the in vitro SPF value of $11.2 \pm 0.4$ at the same concentration of tamanu oil in our study. There is evidence that the triglycerides of tamanu seed oil are not specific in terms of fatty acid composition compared to the vegetable oils examined in this study, i.e., their fatty acids do not contain conjugated double bonds [46-50]. However, unrefined tamanu oil is rich in the unsaponifiable fraction (20-25\%), which consists of oleoresins, xanthones, steroids, triterpenes, and other active compounds, due to which the oil is unusually dark green. Ethanol-soluble oleoresins consist of secondary metabolites such as coumarins (inophyllolides within a phenyl substituent, calanolides within a propyl substituent, and tamanolides within a sec-isobutyl substituent), but the major constituents are always calophyllolides (Fig. 1) —an inophyllum derivatives [47-50]. Because these compounds contain at least one aromatic structure or even another system of conjugated bonds in their molecule, we hypothesize that they can act as natural UVB photoprotective agents and be of interest for further research.

\section{Conclusions}

The aim of this study was to assess (i) the true ability of 14 fixed vegetable oils to act as natural UVB sunscreens and (ii) to verify the suitability of the in vitro dilution method by Mansur et al. for determining their SPF values. The results of our study showed that of the 14 vegetable oils evaluated, only tamanu seed oil exhibits a certain UVB absorption capacity (in vivo SPF value 4.1 and in vitro SPF value 11.2 for concentrated oil). The other 13 oils, also in the concentrated state, showed negligible SPF values (in vivo SPF from 1.2 to 4.5 ), i.e., they can provide no or negligible protection against UVB rays. The in vivo SPF values of the five most promoted oils (carrot seed, coconut, raspberry seed, rosehip seed, and wheat germ) were also very low $(2.5,1.2,2.6,2.6$, and 2.8). The claims shared online about the ability of these oils to protect human skin from UVB radiation are therefore untrue and generally harmful. We have shown that the overestimated SPF values of 4-50 of these oils reported in some publications $[17,18]$ were determined by authors who did not strictly follow Mansur's original methodology. However, this study also demonstrated that the in vitro dilution method is fundamentally flawed in determining an SPF of a substance/ product with such a negligible UVB photoprotection as most vegetable oils can provide. Since the minimum SPF value using the Mansur's equation is "zero", the Mansur's method allows a final SPF value of less than 1 . Such a result is physiologically impossible because the SPF value provided by a substance / product cannot be less than 1 .

On the other hand, it should be noted that only a conventional laboratory spectrophotometer is sufficient for this Mansur's method, in contrast to the special spectrophotometer required for the in vitro PMMA plate method. We therefore consider that, following Mansur's original procedure and taking into account the correct dilution factor, this method may be useful in the research of soluble photoprotective agents as well as in the "rough prediction" of SPF during product development with $\mathrm{SPF} \geq 6$ without physical pigments. However, as already mentioned, the exact SPF value of the photoprotective product must be confirmed by the ISO 24,444:2019 in vivo method in an accredited laboratory.

Author contributions All authors contributed to the study conception and design. Material preparation, data collection and analysis were performed by all authors. The first draft of the manuscript was written by HJ and ÁA and all authors commented on previous versions of the manuscript. All authors read and approved the final manuscript.

Funding This research was supported: by the Slovak Research and Development Agency, project No. APVV-16-0088; by the Ministry of Education, Science, Research and Sport of the Slovak Republic, grant VEGA No. 1/0012/19; by ERDF/ESF project "International competitiveness of NIPH in research, development and education in alternative toxicological methods" (No. CZ.02.1.01/0.0/0.0/16_019/0000860 ); by Ministry of Health, Czech Republic—conceptual development of 
research organization (National Institute of Public Health-NIPH, IN: 75010330"); by Young Research Support Program/ Excellent Team of STU, Slovak Republic, grant No. 1671; and by Young Research Program, grant STU VEFARO No. 1846/2020, Slovak Republic.

Data availability All authors declare that all data and materials as well as software applications, support their published claims and are in accordance with field standards.

Code availability Not applicable for that section.

\section{Compliance with ethical standards}

Conflict of interest The authors have no relevant financial or non-financial interests to disclose. The authors have no conflicts of interest to declare that are relevant to the content of this article.

Ethics approval The selection of ten volunteers for in vivo study as well as the entire study were performed in accordance with the principles described in the World Medical Association (WMA) Declaration of Helsinki for Medical Research Involving Human Subjects [In References No. 33, 34]. The study was approved by the Ethical Review Committee of the National Institute of Public Health in Prague, Czech Republic.

\section{References}

1. Garmyn, M., Young, A. R., \& Miller, S. A. (2018). Mechanisms of and variables affecting UVR photoadaptation in human skin. Photochemical and Photobiological Sciences, 17, 1932-1940.

2. Baker, L. A., Marchetti, B., Karsili, T. N., et al. (2017). Photoprotection: extending lessons learned from studying natural sunscreens to the design of artificial sunscreen constituents. Chemical Society Reviews, 46, 3770-3791.

3. Hojerová, J., Medovčíková, A., \& Mikula, M. (2011). Photoprotective efficacy and photostability of fifteen sunscreen products having the same label SPF subjected to natural sunlight. International Journal of Pharmaceutics, 408(1-2), 27-38.

4. Felton, S. J., Shih, B. B., Watson, R. E. B., et al. (2020). Photoprotection conferred by low level summer sunlight exposures against pro-inflammatory UVR insult. Photochemical and Photobiological Sciences, 19, 810-818.

5. Klimová, Z., Hojerová, J., \& Beránková, M. (2015). Skin absorption and human exposure estimation of three widely discussed UV filters in sunscreens: in vitro study mimicking real-life consumer habits. Food and Chemical Toxicology, 83, 237-250.

6. Hojerová, J., Peráčková, Z., \& Beránková, M. (2017). Margin of safety for two UV filters estimated by in vitro permeation studies mimicking consumer habits: effects of skin shaving and sunscreen reapplication. Food and Chemical Toxicology, 103, 66-78.

7. Hiller, J., Klotz, K., Meyer, S., et al. (2019). Systemic availability of lipophilic organic UV filters through dermal sunscreen exposure. Environment International, 132, 105068.

8. Stoeckelhuber, M., Scherer, M., Peschel, O., et al. (2020). Human metabolism and urinary excretion kinetics of the UV filter Uvinul A plus ${ }^{\circledR}$ after a single oral or dermal dosage. International Journal of Hygiene and Environmental Health, 227(6), 113509.

9. Bom, S., Jorge, J., Ribeiro, H. M., et al. (2019). A step forward on sustainability in the cosmetics industry: a review. Journal of Cleaner Production, 225, 270-290.

10. Wood, E. (2018). Impacts of sunscreens on coral reefs. International Coral Reef Initiative briefing, Feb 2018. https://www.icrif
orum.org/sites/default/files/ICRI_Sunscreen_0.pdf. Accessed 10 Sept 2020

11. Merten, J. W., Roberts, K. J., King, J. L., et al. (2020). Pinterest homemade sunscreens: a recipe for sunburn. Health Communication, 35(9), 1123-1128.

12. Escentials of Australia. (2020). https://www.escentialsofaustrali a.com/products/productid942. Accessed 10 Sept 2020.

13. Natural Sourcing. (2020). Specialist in Cosmeceuticals Ingredients. https://www.praannaturals.com/product-literature/NS_info_ redraspberryseedoil_organic.pdf. Accessed 10 Sept 2020.

14. Pacific Scents. (2020). Natural protection from the sun with vegetable oils. https://pacificscents.com.au/natural-protection-fromthe-sun-with-vegetable-oils. Accessed 10 Sept 2020.

15. Natural Factors (USA/Canada). (2020). https://naturalfactors.com/ en-us/articles/4-uses-for-coconut-oil. Accessed 10 Sept 2020.

16. Oomah, D., Ladet, S., Godfrey, D. V., et al. (2000). Characteristics of raspberry (Rubus idaeus L.) seed oil. Food Chemistry, 69, 187-193.

17. Kaur, C. D., \& Saraf, S. (2010). In vitro sun protection factor determination of herbal oils used in cosmetics. Pharmacognosy Research, 2, 22-25.

18. Suryawanshi, J. A. S. (2016). In-vitro determination of sun protection factor and evaluation of herbal oils. International Journal of Pharmacology Research, 6(1), 37-43.

19. Ranjithkumar, J., Sameesh, A., \& Ramakrishnan, H. (2016). Sunscreen efficacy of Punica granatum (Pomegranate) and Citrullus colocynthis (Indrayani) seed oils. International Journal of Advanced Research in Biological Sciences, 10(3), 198-206.

20. de Souza, C. M. P., dos Santos, P. G. G., Santana, C., et al. (2014). Physicochemical characterization and in vitro evaluation of the photoprotective activity of the oil from Opuntia ficus-indica (L.) Mill seeds. African Journal of Pharmacy and Pharmacology, 48(8), 824-831. http://www.iosrjournals.org/iosr-jrme/papers/ Vol-5\%20Issue-1/Version-3/A05130105.pdf. Accessed 10 Sept 2020 .

21. Kumar, K. A., \& Viswanathan, K. (2013). Study of UV transmission through a few edible oils and chicken oil. Journal of Spectroscopy, 28, 1-5. https://www.hindawi.com/journals/jspec /2013/540417/. Accessed 10 Sept 2020.

22. Gause, S., \& Chauhan, A. (2016). UV-blocking potential of oils and juices. International Journal Cosmetic Science, 38(4), 354-363.

23. Mansur, J. S., Breder, M. N. R., Mansur, M. C. A., et al. (1986). Determinação do fator de proteção solar por espectrofotometria (Determination of sun protection factor by spectrophotometric methods). Anais Brasileiros de Dermatologia, 61, 121-124.

24. Mansur, J. S., Breder, M. N. R., Mansur, M. C. A., et al. (1986). Correlação entre a determinação do fator de proteção solar em seres humanos e por espectrofotometria (Correlation of sun protecting factor in human beings and by spectrophotometry). Anais Brasileiros de Dermatologia., 61, 167-172.

25. FDA. (2019). US food and drug administration, CFR: code of federal regulations title 21 (1), Sec. 352.70 Standard sunscreen. Revised as of April 1, 2019. https://www.ecfr.gov/cgi-bin/textidx?SID $=$ e864e020bb35619e319dfcab7180a049\&mc $=$ true \&no $\mathrm{de}=\mathrm{se} 21.5 .352 \_170 \& \mathrm{rgn}=\operatorname{div} 8$. Accessed 10 Sept 2020.

26. ISO 24444:2019 (2019). Cosmetics: sun protection test methods: in vivo determination of the sun protection factor (SPF). ISO/ TC 217 Cosmetics ICS: 71.100.70, 59. https://www.iso.org/stand ard/72250.html. Accessed 10 Sept 2020.

27. Pissavini, M., Marguerie, S., and Doucet, O. (2016). SPF tests reveal no ideal in vitro substrate exists. Cosmetic and Toiletries, 131, 20-30. https://www.cosmeticsandtoiletries.com/testing/spf/ SPF-Tests-Reveal-No-Ideal-In-vitro-Substrate-Exists-375272221. html. Accessed 10 Sept 2020. 
28. Bendová, H., Akrman, J., Krejčí, A., et al. (2007). In vitro approaches to evaluation of sun protection factor. Toxicology in Vitro, 2, 1268-1275.

29. Pissavini, M., Tricaud, C., Wiener, G., et al. (2020). Validation of a new in vitro sun protection factor (SPF) method to include a wide range of sunscreen product emulsion types. International Journal of Cosmetic Science, 42, 421-428.

30. Sayre, R. M., Agin, P. P., LeVee, G. J., et al. (1979). Comparison of in vivo and in vitro testing of sunscreening formulas. Photochemistry and Photobiology, 29(3), 559-566.

31. Lowe, N. J., \& Breeding, J. (1983). Sunscreen predictive assays: Alternative assays that measure the ability of different sunscreens to protect against epidermal and dermal effects of ultraviolet irradiation. Cosmetics and Toiletries, 98, 65-68.

32. Solar light. SPF testing multiport 6-channel light source. Model 601 v.2. https://solarlight.com/wp-content/uploads/2008/12/Simul ators_601-v2-5.pdf. Accessed 10 Sept 2020.

33. Council for international organizations of medical sciences (CIOMS). (2016). International ethical guidelines for healthrelated research involving humans. https://cioms.ch/wp-content/ uploads/2017/01/WEB-CIOMS-EthicalGuidelines.pdf. Accessed 10 Sept 2020.

34. WMA Declaration of Helsinki (2013). Ethical principles for medical research involving human subjects, 1964, amended 2013.https ://www.wma.net/policies-post/wma-declaration-of-helsinki-ethic al-principles-for-medical-research-involving-human-subjects. Accessed 10Sept 2020.

35. Yang, S. I., Liu, S., Brooks, G. J., et al. (2018). Reliable and simple spectrophotometric determination of sun protection factor: A case study using organic UV filter-based sunscreen products. Journal of Cosmetic Dermatology, 17, 518-522.

36. Sudhahar, V., anf Balasubramanian, V. (2013). Sun production factor (SPF) determination of marketed sunscreen formulation by in-vitro method using UV-VIS spectrophotometer. Archives of Applied Science Research, 5(6), 119-122. http://scholarsresearc hlibrary.com/archive.html>. Accessed 10 Sept 2020.

37. Dutra, E. A., Oliveira, D. A., Kedor-Hackmann, L. G., et al. (2004). Determination of sun protection factor (SPF) of sunscreens by ultraviolet spectrophotometry. (Revista Brasileira de Ciências Farmacêutica) Brazilian Journal of Pharmaceutical Sciences, 40(3), 381-385. https://doi.org/10.1590/S1516-93322 004000300014>. Accessed 10 Sept 2020.

38. Mesías, L. G. G., Qwisgaard, A. M. R., Untivero, G. P. C., et al. (2017). Comparison of the photoprotective effects of sunscreens using spectrophotometric measurements or the survivability of yeast cells exposed to UV radiation. Revista de la Sociedad Química del Perú, 83(3), 294-307. URL: <http://www.scielo.org. pe/pdf/rsqp/v83n3/a05v83n3.pdf > . Accessed 10 Sept 2020.

39. Montenegro, L., \& Santagati, L. M. (2019). Use of vegetable oils to improve the sun protection factor of sunscreen formulations. Cosmetics, 6(25), 1-10.

40. Wagemaker, T. A. L., Carvalho, C. R. L., \& Filho, O. G. (2011). Sun protection factor, content, and composition of lipid of green coffee beans. Industrial Crops and Products, 33, 469-473.

41. Runger, T. M. (2003). Ultraviolet light. In: Bolognia, J. L., Jorizzo, J. L., and Rapini, R. P. (Eds.), Dermatology (vol. 2, 1st ed., Chapter 86, pp. 1353-1357). London: Mosby.

42. Alfeetouri, O. H., Mosa, F. A., \& Jibreel, W. A. (2019). Determination of sun protection factor (SPF) of some botanical oils by ultraviolet spectrophotometry. The Libyan Conference on Chemistry and Its Applications LCCA, 1(1), 52-58.

43. Healthline, DIY sunscreen recipes. URL: <https://www.healt hline.com/health/homemade-sunscreen\#diy-recipes $>$. Accessed 10 Sept 2020.

44. Kanellis, V. G. (2020). Sharing recipes and creating potentially dangerous homemade sunscreens. Australasian Journal of Dermatology, 61(2), 161-161.

45. Lim, T. L. C. (2020). Sunscreen: "Do-It-Yourself" (DIY) does not mean enough protection. Our Dermatology Online, 11(3), 273-274.

46. Anonym. (2014). Tamanu original unrefined oil. Pacifique Sud Ingredients, Aubagne, France, 10 pgs. URL: <http://www.eurot radingonline.it/wp-content/uploads/2017/07/Ti_TAMANU_OIL. pdf $>$. Accessed 10 Sept 2020.

47. Rejeki, S. S., and Wahyuningsih, S. (2015). Formulasi gel tabir surya minyak nyamplung (tamanu oil) dan uji nilai SPF secara in vitro. University Research Colloquium, Indonesia, 97-103. http://hdl.handle.net/11617/5168>. Accessed 10 Sept 2020.

48. Lim, T.K. (2012). Calophyllum inophyllum. In: Edible Medicinal and Non-Medicinal Plants (pp. 7-20). Dordrecht: Springer Science and Business MediaB.V. https://doi. org/10.1007/978-94-007-1764-0_2.

49. Léguillier, T., Lecsö-Bornet, M., Lémus, C. H., et al. (2015). The wound healing and antibacterial activity of five ethnomedical Calophyllum inophyllum oils: an alternative therapeutic strategy to treat infected wounds. PLOS ONE, 10(9), e0138602.

50. Ansel, L. J., Lupo, E., Mijouin, L., et al. (2016). Biological activity of Polynesian Calophyllum inophyllum oil extract on human skin cells. Planta Medica, 82(11-12), 961-966. 